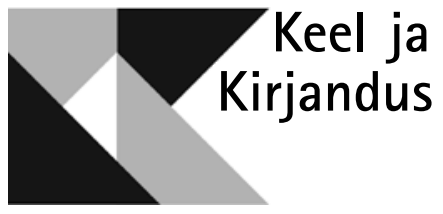

LVIII AASTAKÄIK

EESTI TEADUSTE AKADEEMIA JA EESTI KIRJANIKE LIIDU AJAKIRI

\title{
MIKS AVALDADA MONOGRAAFIAT?
}

\author{
LEO LUKS
}

A rtikli pealkiri on kitsendus avaramast küsimusest: miks avaldada ra a m atut? Viimane küsimus on kardetavasti hoomamatult lai. Järgnevas arutluses kitsendan küsimuse peaaegu juhtumianalüüsiks, kasutades näitena oma hiljutise monograafia (Luks 2015) avaldamise kogemust. Kuigi raamatu koostamise kogemus on värske, pole minu jaoks sugugi lihtne jõuda selgusele, miks ma seda tegin - siin tunduvad segunevat ja hägustuvat paljud erinevad kaalutlused.

Ühest küljest aheneb mu uurimisobjekt tohutult, aga teisest küljest laieneb uurimisväli samavõrd. Küsides, miks midagi teha, küsime tegevuse aluste järele. Mul ei ole kavas laskuda siinkohal tahtevabaduse probleemi sügavikku; eeldan, et inimesel on võimalik üldjuhul valida, kas avaldada raamat või mitte. Vaevalt jõuab inimene seejuures kõik asjaolud teadlikult läbi kaaluda, küllap mõjutavad seda otsust mitmed üldised kultuurilised tegurid, mille keskel inimene on kasvanud.

Laiem küsimus, mis mind tõeliselt huvitab ning mida üritan raamatu avaldamise näitel analüüsida, on järgmine: kas meie teadlikud valikud ${ }^{1}$ on läbinisti või vähemalt valdavalt ökonoomilised, kasu-kahju rehkendusel tuginevad, või leidub meie elus tegusid, mis on väljaspool säärast oravaratast? Küsimus pole kuigi originaalne, sellega on maadelnud suur hulk viimase sajandi mõtlejatest.

\footnotetext{
${ }^{1}$ Ma ei analüüsi seega teadvustamata käitumist, nagu paljud argielu automatismid või ka instinktiivne käitumine ohusituatsioonis. Raamatu avaldamine pole kahtlemata instinktiivne käitumine ning sobib seega näiteks hästi.
} 
Järgnevat käsitust saab pidada esialgseks mõttevisandiks kõnealusel teemal. Teemat avades pean vajalikuks läbida kolm mõttesammu: vaatlen raamatut ökonoomilise ühikuna, annina ning fetišina.

\section{Raamat kui ökonoomiline ühik}

Esmalt tuleb täpsustada, mida ma pean silmas ökonoomilisuse all. Paljude kontinentaalfilosoofide eeskujul ei kasuta ma seda mõistet kitsalt majandussüsteemi ega inimeste majanduslike kaalutluste kirjeldamiseks, kuigi meie analüüs algab sellelt tasandilt. Paljud mõjukad mõtlejad on kritiseerinud ökonoomilisust ilma seda mõistet piiritlemata, püüan siinkohal täpsem olla.

„Eesti keele seletav sõnaraamat” fikseerib samast tüvest tuleneva kahe pisut erineva termini tähendused:

ökonoomia - 1. sääst(mine), kokkuhoid(mine); säästlikkus, kokkuhoidlikkus.

2. majandusteaduse omaaegne nimetus. Poliitiline ökonoomia. ${ }^{2}$

ökonoomika - 1. majandustegevus, majandamine.

2. hrl. liitsõna järelosana esineb majandusteaduse harude nimetustes. Masinaehituse ökonoomika. ${ }^{3}$

Alapealkirjas välja kuulutatud ökonoomiline tähendab selle eristuse järgi ökonoomikasse puutuvat, majanduslikku4; ökonoomiaga kaasub omadussõna ökonoomne . $^{\text {. }}$.

Selles eristuses on oma paradoksaalsus, ühelt poolt oleks ökonoomia (2. tähenduses) teadus ökonoomiast; teiselt poolt on jällegi ökonoomika ökonoomia harusid nimetavate liitsõnade osa (vt pikemalt Mereste 1980).

Siinse käsituse huvifookus on ökonoomia mõiste 1. tähenduse juures, kuid seda hästi avaralt mõelduna. Kui ma küsin, kas meie valikud (sh valik avaldada raamat) on läbinisti ökonoomilised, siis pean silmas lootmist äratasumisele, kasulikkusele avaramas mõttes; ratsionaalset põhjuste-tagajärgede kaalumist; rehkendamist; kõige mõtestamist mõju ja vastasmõju kaudu. Selle hoiaku käsitlemiseks ei piisa üksnes kitsalt majandusteadusest pärinevate terminite rakendamisest, kuigi rahas mõõtmine on tänapäeva ökonoomia levinuim lähenemisviis. Võib öelda, et ökonoomia mõiste triivib eri autoritel kahe äärmuse vahel: ühes otsas mõistetakse seda kitsalt majandustegevusena, teiseks äärmuseks on omistada kogu tegelikkusele (st loodusele) ökonoomilisus, st iseorganiseerumine, optimaalse soorituse poole „püüdlemine” põhjuse-tagajärje seoste varal (vt Bulgakov 2000: 72-73). Ma ei pretendeeri viimati kirjeldatud metafüüsilisele haardele, vaid piirdun inimühiskonna käsitlemisega, kuigi ka loodusteaduslik mehhanitsistlik maailmapilt on näide ökonoomilise mõtlemise laiendusest. Oma lähenemisviisi valikuga ei arva ma samas, nagu oleks õige käsitleda ökonoomilise mõtlemise ülimuslikkust üksikisikute vabatahtliku teadliku kokkuleppena, millest võiks iga kell loobuda: vähemalt Marxist peale on filosoofias löödud ökonomismile hädakella, mis pole aga siiski

\footnotetext{
${ }^{2} \mathrm{http} / / /$ www.eki.ee/dict/ekss/index.cgi?Q=\%C3\%B6konoomia\&F=M

${ }^{3} \mathrm{http} / / / \mathrm{www}$. eki.ee/dict/ekss/index.cgi?Q=\%C3\%B6konoomika\&F=M

${ }^{4} \mathrm{http}: / /$ www.eki.ee/dict/ekss/index.cgi?Q=\%C3\%B6konoomiline\& $\mathrm{F}=\mathrm{M}$

${ }^{5} \mathrm{http}: / /$ www.eki.ee/dict/ekss/index.cgi?Q=\%C3\%B6konoomne\&F=M
} 
andnud põhjust lõplikult lüüa hingekella sellel mõtteviisil tuginevale tsivilisatsioonile. Kindlasti moodustavad laiema leviga mõtteviisid ja hoiakud üksikisikute jaoks ajaloolise aprioorsuse (vt Foucault 2005: 113-115), kuid pole samas mitte tingimata vääramatud. See, et me nende protsesside üle ja neile vastu mõelda üritame, näitab juba teatavat emantsipatsioonilist potentsiaali.

\subsection{Raamat kaubana ja sümboolse kapitalina}

Tulles tagasi alapealkirja juurde, vaatlen esmalt raamatut kitsalt turumajandusliku ühikuna, kaubana. Selline lähtepunkt võib tunduda raamatu pühadust teotav, kuid me ei saa seda aspekti eirata - raamatute ringlus toimub ju samuti valdavalt turu vahendusel, kirjastuste kui ettevõtete loodud toodanguna. Turumajanduse loogikast lähtudes tundub õige, et inimene, kelle põhitegevuseks on raamatute kirjutamine (kirjanik, esseist), teenib oma elatusvahendid raamatute müügist. Samas on teada, et see loogika Eesti raamatuturul ei toimi: isegi paari kohalikus mõistes menuki kirjutamine ei taga autorile majanduslikku sõltumatust. Eestikeelse teaduskirjanduse või humanitaarse esseistika puhul oleks majandusliku edu lootmine sulaselge sõgedus. Autori positsioonilt rääkides tuleb täpsustada, et teaduskirjanduse puhul on ülemaailmne tava loovutada oma looming kirjastusele tasuta. Rahvusvahelises perspektiivis on see viinud olukorrani, kus suured kirjastuskorporatsioonid riisuvad raamatute, aga eriti just erialaajakirjade müügist kopsakaid kasumeid, ${ }^{6}$ kuid Eestis trükitavate tiraažide põhjal ei saa me sellest rääkida.

On küll õige välja tuua, et erialaste raamatute kirjutamine käib akadeemilise töötaja tööaja sisse ning saab tasutud igakuise palga näol. Samas tuleb rõhutada, et mitte keegi ei nõua Eestis teadustöötajatelt monograafiate kirjutamist, see aeganõudev tegevus võib isegi unarusse jätta paljud teised asjad, mida inimeselt nõutakse. See viib meid järgmise alateemani.

Teiseks tasub meil vaatlust veidi laiendada, väites, et mitte kogu kasu ei avaldu vahetult ja koheselt rahas. Selle vaateviisi on hõlmavalt välja arendanud siinmailgi populaarne prantsuse sotsioloog Pierre Bourdieu oma eri liiki kapitalide ja nende konverteeritavuse teoorias. Raamat kui objektiveeritud kultuuriline kapital (Käärik 2013: 282) võib tugevdada autori olemasolevaid erialaseid suhteid ja tekitada uusi (st suurendada sotsiaalset kapitali); tõsta autori erialast prestiiži (suurendada sümboolset kapitali), mis kõik omakorda peaks andma ka rahalise võidu (parem töökoht, grant vms). Filosoofia ajaloost on teada palju juhtumeid, kus just mõne läbimurdeteose avaldamise järel pakuti autorile professuuri.

Akadeemilise loometegevuse väärtust on Eestis juba mitmeid aastaid üritatud mõõta kurikuulsa teadusinfo klassifikaatorite süsteemi abil. ${ }^{7}$ Tolle maailmaga kursis olevad inimesed teavad hästi, et sealse hierarhia A ja O on teadusartikkel. Artikleid nõutakse nii kraadide kaitsmisel, ametikohtade kui ka grantide taotlemisel; ka monograafiate jaoks on oma nurgake, kuid raamatu olemasolu ei asenda üheski kategoorias artikleid. ${ }^{8}$

\footnotetext{
${ }^{6}$ Selle tendentsi vastu on viimastel aastatel tekkinud mõjukas opositsioon, mis nõuab, et avaliku raha toel loodud teadustulemused jõuaksid üldsuseni tasuta, ilma turumajanduslike „puukide” vahenduseta, vt Allik 2014: 1558-1561.

${ }^{7}$ www.etis.ee/otsingud/classification.aspx

8 Tähendusrikas on seegi tõik, et mitmete muudatuste järel märgistatakse nüüdsest ETIS-es kõik teadusmonograafiad armulikult kategooriaga 2.1.
} 
Võib küll hellitada lootust, et geniaalne monograafia avab tänagi uksed kaugete maade tippülikoolides, kuid mingil juhul ei tee seda eestikeelne raamat. Kuigi ajaloolased, keele- ja kirjandusteadlased avaldavad veel monograafiaid märkimisväärsel hulgal, on eesti filosoofid selle tegevuse mõttetusest ammugi aru saanud: 24 iseseisvusaasta jooksul on kutselistelt filosoofidelt ilmunud kaks eestikeelset monograafiat. ${ }^{9}$ Seega pole mingit tõendit, et akadeemilisel raamatul oleks kultuurilise kapitali ühikuna Eestis selge konverteeritav väärtus.

\subsection{Tagasi kasutusväärtuse juurde?}

Peatugem siinkohal hetkeks ja püüdkem teha esimene väljamurre ökonoomilisest mõtlemisest. Kas ei ole meie arutelu siiani liikunud Karl Marxi (1953: 70-80) diagnoositud kaubafetišismi lummuses: käsitlesime raamatut kaubana, tema võimalikku vahetusväärtust erinevates kapitali-korrastikes. Kuid kas pole siis raamatu puhul esmatähtis tema sisu, tema $k a-$ sutusväärtus potentsiaalse lugeja jaoks? Rääkides kitsamalt ilukirjandusest ja filosoofiast, mille piirjooni ka minu monograafia kompab, oleks ehk kohane rõhutada vaimsete väärtuste esmasust. Ükskõik, kas viimased on omakorda püsiväärtused, meie kõigi kaotsi läinud ühised väärtused või midagi vähem üllast, ometigi ei ole need kasulikud pelgalt instrumentaalses mõttes (nagu võib olla näiteks raamat raamatupidamise alustest või autoremondist). Me ju ometigi vajame raamatuid. Inimesed avaldavadki raamatuid selle vajaduse rahuldamiseks, pöörduvad publiku poole, sest neil on sõnum, on oma lugu rääkida, laulud laulda; ei saa mitte vaiki olla! Teaduslike ja filosoofiliste raamatute toel liigume edasi üha uute teadmiste poole ning ehk ka üleüldise külluse ja igavese rahu poole. ${ }^{10}$ Küllap mõtestavad paljud humanitaarid monograafilise raamatu kirjutamist teatud vastupanuaktina artikleid väljanõudva teadusbürokraatliku süsteemi vastu - artiklis toimub ainult mõtlemise simuleerimine, raamat on päris asi!

Kahtlemata on eespool kirjeldatud üllad tunded innustanud autorite horde oma teoseid avaldama, kuid paraku pole minust eelneva hosianna edasilauljat. Siinse käsitluse näiteks valitud raamatus visandatud nihilismi mõtlemine ei jaga püsiväärtuste ennistamise eesmärki; kuigi seal teostatakse mitmeid rünnakuid settinud institutsionaalse korralduse suunas (sh teaduse vastu, vt Luks 2015: 15-17), ei ole mõtlemise paatos kantud n-ö uue alguse lootusest. Sellist lootust käsitlen ideoloogilise lõksuna, kuhu üha uued filosoofid langevad, halvimal juhul oma innustuses mõtlemist reaalpoliitilistele jõududele välja jagades. Samuti ei hellita ma lootust, et raamat pälvib kaalukama vormi tõttu artiklitest laiema lugejate tähelepanu. Monograafia terviklikkus - isegi kui see on näiline, pelgalt kompositsiooniline võte - kohustab potentsiaalset lugejat ohverdama kordades rohkem aega võrreldes võimalusega lugeda eraldi mõnda artiklit (vt ka Zaid 2011: 45-47).

Üldisemalt kõneldes ei aita meid ökonoomilisest oravarattast välja lähenemisviisi teisendus, mille kohaselt ei tule keskenduda mitte asjadele kui

${ }^{9}$ Lisaks siinkirjutajale on raamatu avaldanud ka Andrus Tool (2014). Peagi on tulekul kolmas monograafia Margus Otilt. Kõik kolm on kas doktoritööd või nende edasiarendused. Artiklikogumikke ja õppevara on avaldatud mõistagi rohkem.

${ }^{10}$ Selles valgustusfilosoofia lootuses lipsas jälle sisse instrumentaalsus, teadmisteväline kasu. 
kaupadele (ehk nende vahetusväärtusele), vaid hoopiski nende tegelikule kasutusväärtusele. Selline ettepanek sisaldub Marxi omaaegses kriitikas poliitökonoomiale, kuid paljud kaasaegsed lugemised on toonud esile säärasele lähenemisele omast naiivset idealismi. Pean õigeks seisukohta, mille kohaselt on asja kasutusväärtus alati juba vahetusväärtuse poolt nakatunud (Laclau 2015: 227). Vahetusväärtuste põhisest mõtlemisest lahtisaamise projekt eeldab turuvaba asjade ringluse mudelit (Marxi utoopia), see omakorda aga eeldab loomulike mõõdukate vajadustega subjekti, mingit versiooni Rousseau õilsast metslasest. Ehk siis pole kasutusväärtuse poole pöördumisest mingit kasu, kui sellega ei kaasne püsiväärtuste taasleidmise lugu. Nagu rõhutab Jean-Joseph Goux (1990: 221), on kitsalt majandusteaduslik lähenemine aksioloogilises plaanis täiesti ükskõikne küsimuses, mida keegi soovib või peaks soovima tarbida. Turust-vabaks emantsipatsioonilugu ei pajata meile mitte ennekõike sellest, et asjade ringlus raha vahendusel oleks tehnilise printsiibina vildakas: põhiprobleem on selles, et ringlust ja kasvu vajav süsteem kehutab subjekte ihaldama üha rohkem asju, mida neil te g e likult vaja ei oleks. Nõnda kulutavad nad oma elu kassikulla tagaajamisele ning püsiväärtused jäävad unarusse. Seda mõttekäiku saab vägagi edukalt illustreerida raamatu abil: meid ümbritseb muu rämpsu kõrval ammugi juba liiga suur hulk raamatuid (vt Zaid 2011) ning kuna raamat kaubana vajab võimalikult suurt läbimüüki, kirjastatakse masside püüdmiseks hulganisti lihtsakoelist meelelahutust, nagu skandaalsed elulood, kerged reisikirjad, esoteerika, kokaraamatud jms. Säärast kraami ostetakse kordades rohkem kui süvaluulet või filosoofiamonograafiat (sh ka Eestis), järelikult saame olukorrale moraalse hinnangu anda üksnes juhul, kui suudame visandada inimese loomulike vajaduste või siis inimsuse ideed arendavate vajaduste nimistu. Ka sellistest projektidest on filosoofia tulvil.

Jean Baudrillard jõuab oma põnevas essees „Märgi poliitökonoomia kriitikaks” (1988a) oluliste järeldusteni. Kasutusväärtuse ja vahetusväärtuse vahel ei ole tema jaoks põhimõttelist vahet, mõlemast mõeldakse sarnase loogika alusel, milleks on abstraktse ekvivalentsuse kood. „Et saaks olla majanduslikku vahetust ja vahetusväärtust, selleks on hädavajalik, et kasulikkuse printsiip oleks juba saanud objekti või toote reaalsuse printsiibiks" (Baudrillard 1988a: 65). Kuigi kasutusväärtus ei ole kvantitatiivne rangelt aritmeetilises mõttes, sisaldab see siiski ekvivalentsust. Kasulike väärtustena mõelduna on kõik hüved juba üksteisega võrreldavad (Baudrillard 1988a: 65); kasutusväärtus on samuti sotsiaalne suhe, mitte asjade loomus (Baudrillard 1988a: 66).

Veelgi enam, kui määratleme inimese vajaduste kaudu (domineeriv viis kaasajal leida n-ö madalaim nimetaja eri kultuuride vahel, vajaduste demokraatia, Baudrillard 1988a: 71), siis mõtleme seeläbi temast juba läbinisti ökonoomilistes terminites (Baudrillard 1988a: 67) - on üksnes tehniline nüansierinevus, kas me käsitleme normaalsusena üha kasvavate vajaduste üleüldise rahuldamise tulevikulist seisundit (liberalistlik utoopia) või hoopis süvaökoloogilist rehkendust, n-ö majandamist kooskõlas ressursside piiratusega. Baudrillard analüüsib siin detailsemalt üldist nähtust, mille sõnastas juba Heidegger: asi pole mitte õigete väärtuste sõnastamises; kogu rehkendav väärtusmõtlemine on juba nihilism, olemisunustus (vt Heidegger 1961: 335-398).

Baudrillard mõtiskleb refereeritud essees süvitsi ka keele üle. Asjalood pole sugugi nii lihtsad, nagu võiksime omatahtsi rehkendavat mõtlemist muu- 
ta, hakata keelt teisiti tarvitama. Baudrillard visandab olulise seose kaubaloogika ja üldise tähistusloogika vahel; tähistaja/tähistatava suhet võib vaadelda analoogselt vahetusväärtuse/kasutusväärtuse suhtele, kusjuures samamoodi seostuvad nostalgiline ootus vabaneda vahetusväärtuse suvalisusest ning tähistaja arbitraarsusest. Keeles toimiv range tähistamissuhe on samuti ökonoomiline ning teeb võimalikuks märgi ja kauba ühtesulamise. Ühelt poolt võtab kapitalistlikus vaatemänguühiskonnas kaup üle tähistamise efekti totaalse meediumina (Baudrillard 1988a: 78) ning kehtib ka vastupidine:

Kaubaloogika ja poliitiline ökonoomia asub päris märgi südames, tähistaja ja tähistatava abstraktses võrdsustamises, märkide erinevusliku kombinatoorika tõttu, sestap saavad märgid funktsioneerida vahetusväärtusena (kommunikatsiooni diskursus) ja kasutusväärtusena (sotsiaalse kasutuse ratsionaalne dekodeerimine) (Baudrillard 1988a: 78).

Vahekokkuvõtteks tuleb seega öelda, et katsetatud väljamurre ebaõnnestus. Ökonoomilisest mõtlemisest ei saa vabaneda pelgalt nii, et loobume rahas rehkendamisest ning võtame rehkenduse aluseks püsiväärtused või kas või paradoksaalse iseväärtuse. Mis tahes ratsionaalne-utilitaarne mõtlemine jääb ökonoomiliseks, seda seotust võimendab salamahti keele instrumentaalne tähistusmehhanism.

\subsection{Naudingute pruuk}

Jätkan mõtisklust ökonoomiliselt horisondilt väljapääsemise võimalikkusest järgmises alapeatükis, enne seda viin k olm a n d a ks ja viimaks läbi veel ühe ökonoomilise rehkenduse, sedakorda naudingute vallas. Jättes kõrvale kirjatööle omistatava missiooni, võib küsida: kas raamatu kirjutamine ja teised selle avaldamisega seotud tegevused on protsessina nauditavad? Kuna need protsessid on nii raamatu kui ka autori eripärast sõltuvalt sügavalt isiklikud, ei saa ma siinkohal pretendeerida muule kui isikliku kogemuse meenutamisele.

Kindlasti on kirjutamine heas mõttes maania, grafomaania, kirjutamise hull mäng, millega kaasneb mõtlemise ületulv. Sellesse maaniasse kuuluvad nii voolava edenemise tekstimõnu kui ka õigete sõnade viibimise ängistav nauding. ${ }^{11}$ Kindlasti võib ka monograafia kirjutamise protsessi nautida, eriti kui kirjutatakse ennast huvitaval teemal ning kui autor usub, et tal on esitada publikule tähtis, hariv-valgustuslik sõnum. Artiklite mahupiirangute ökonoomsusprintsiibi poolt räsitud intellektuaalidele võib lisanaudingut pakkuda tunne, et monograafiat kirjutades ei pea oma mõttekäiku igal sammul kärpima ja kokku suruma.

Paraku ei valmi monograafiad pahatihti tervikliku loomedünaamika printsiibi alusel - seda peab ütlema ka minu raamatu kohta. Sageli kompileeritakse monograafia hoopiski käepärasest materjalist ehk siis temaatiliselt haakuvatest artiklitest - siin ei toimi mingit kirjutamise hullu mängu, vaid heal juhul see, mida üks minu käsikirja anonüümne retsensent nimetas poeetiliselt „elavaks rüseluseks struktuuri leidmise nimel”. Tuleb lappida auke, teksti korduvalt ümber tõsta, jupikesi juurde kirjutada ja teisalt maha kustutada jne. Sama rüselus toimub vähemalt kolm korda: algul oma tarkusest, seejärel

${ }^{11}$ Vrd mõnu- ja naudinguteksti mõistetega: Barthes 2007. 
retsensentide nõudmisel ning viimaks toimetaja märkuste põhjal. Võib-olla mõned perfektsionistid naudivad sedagi protsessi, küllap muutub tekst nõnda pisut täpsemaks ja selgemaks. Võib isegi oletada, et mõnikord jõutakse mõtete viimistlemise käigus mõne uue avastuseni. Oma kogemuse põhjal julgen öelda, et säärane nikerdamine on pigem tüütu, ei paku mõtlemisele piisavalt pinget ning takistab uute teemade juurde liikumist. Kui lisada naudingute rehkendusse juba eelnevalt käsitletud ajafaktor - mõtlemise aeg saab otsa, päevad on loetud -, siis saab järeldus olla ühene: vähemalt varem avaldatud tekstide $^{12}$ põhjal monograafia koostamine ei tasu ära. Pole seega ime, et leidub loojaid, kes kirjutavad palavikuliselt kokku hoomamatuid tekstimassiive, kuid avaldavad elu jooksul väga vähe.

Tuleb öelda, et eestikeelse humanitaarmonograafia avaldamine ei tasu ära üheski seni vaadeldud ökonoomilises mõttes. Samas motiveerivad reaalelus autoreid monograafiaid koostama küllap mitmed eelnevalt visandatud lootused läbisegi, neid innustavad mitmed enesepettuse skeemid (ennekõike alahinnatakse tööle asudes alati n-ö tehnilisteks töödeks kuluvat ajamahtu). Senise analüüsi põhjal oleks ennatlik järeldada, et raamatu avaldamine on täiesti irratsionaalne akt.

\section{Raamat kui and}

Selles peatükis võtan kaalumisele teise võimaliku väljamurde ökon o o miast ning küsin, kas eestikeelse monograafia avaldamine on täiesti kasutu akt, isetu and. Ehk ongi loomingu esmaseks impulsiks ennast lihtsalt väljendada, kinkida loodu ilma tasu lootuseta ära? Miks muidu on loojad sedavõrd vastalised moodsa aja üleskutsetele mõtelda-tegutseda loomemajanduslike üksustena. See hüpotees väärib kaalumist: just anni mõiste on üks paljudest, mille kaudu kaasaja mõtlejad on üritanud ökonoomilisest ruumist väljapääsu leida.

Asi on siiski pisut keerulisem. Alustuseks tuleb meil eristada andi (ingl Gift, sks Gabe) kingitusest (Present, Geschenk). Juba vähemalt Marcel Maussi 1925. aasta klassikalisest uurimusest saati teame, et kingitus on täiesti ökonoomiline ühik, mida organiseerib väga selge ringluse ja vastastikkuse printsiip. N-ö primitiivseid kultuure uurides leidis Mauss, et kinke ei tehta juhuslikult, vaid neid reguleerivad mitmesugused reeglid, millest universaalseim on just vastukingi tegemise kohustus (Mauss 2015). See põhimõte on osaliselt kandunud üle tänasesse päeva, nt kohustusena teha jõulu- ja sünnipäevakinke. Kindlasti mõjutas kingiökonoomia olulisel määral ka minu raamatu koostamise otsust: olin aegade jooksul saanud tuttavatelt kingituseks terve riiulitäie raamatuid, enamasti doktoritöid, ning vastukingi kohustus rõhus. Nagu näeme, on see mõtteviis läbinisti ökonoomiline: ma ei jaganud oma raamatu autorieksemplare anonüümsetele vastutulijatele, vaid nendele, kelle ees tundsin materiaalset või vaimset võlatunnet (nt doktoritöö juhendajad).

Mõtteeksperimendi korras võiksime oletada, et leidub autor, keda ei paina kinkimiskohustus; kas pole ta kelleltki kinke saanud või on näiteks just äsja

${ }^{12}$ Kui materjalid on avaldamata, siis saaks nende monograafiasse koondamise kasuks esitada tagasiside argumendi: avaldamisele järgnev võimalik kriitika ja tagasiside võib mõtlemist edasi aidata, pakkuda uut inspiratsiooni. 
mõne eelneva raamatuga n-ö võlad ära õiendanud. Lisaks oletagem, et autor ei saa monograafia eest kopikatki honorari ega usu, et tema teosest sünnib üldsusele või isamaale käegakatsutavat kasu. Kas sellisel juhul oleks tegemist ökonoomiast välja ulatuva annetusega, ehk isegi ohverdusega - raamatu kirjutamiseks-toimetamiseks kulunud autori elamise aja ohverdusega? Mitte tingimata! Selle mõtteeksperimendiga oleme liginenud George Bataille' üldise ökonoomia ja kulutuse mõistetele (Bataille 1997: 167-198). Olgu öeldud, et majanduslikul kasul toimivat rehkendust nimetab Bataille piiratud ökonoomiaks (Bataille 1997: 197) ning üldine, laiendatud ökonoomia on tema katse sellest välja pääseda.

Miks kulutada midagi täiesti kasutult, lootmata midagi vastu saada - meie näite puhul kulutati loomingulist energiat ja elamise aega? Võime siinkohal tõmmata paralleeli rikkuste laushävitamisega loodusrahvaste rituaalides. Nagu analüüsis juba Mauss (2015: 136), pole säärane tegevus vaba enesekesksusest, vaid siin on mängus rivaliteet, võistluslikkus - antropoloogiline termin selle protsessi kohta on potlatš (Mauss 2015: 37). Kingiökonoomia kutsub võistlema; puhta kulutusega kaasneb prestiiž, kingitusele tuleb ideaalis vastata mitte samaväärse, vaid suurema kingiga. Kinkija või väärtuslike asjade hävitaja näitab oma ülemvõimu, saavutatud energia ülejääki (meenutagem kas või Kassiaru Jaska rahapõletamist „Tões ja õiguses”).

Bataille omistab sellistele nähtustele üldise ökonoomia seisukohalt keskse tähenduse, kuna tema nägemuse kohaselt iseloomustab energiat alati ülejääk (Bataille 1997: 185), millest tuleneb ebaproduktiivse kulutuse vajalikkus (nt ohver, luksus, sõda, vaatemängud jne; Bataille 1997: 169). Säästlikkusel ja utilitaarsusel tuginev mõtteviis piirab inimloomust, lõikab läbi tema seosed pühaga - püha leiab aset üksnes kaotuse operatsiooni kaudu (Bataille 1997: 170). Spekulatsiooni korras võiks visandada sellise seose: endale vabalt uurimisvaldkonda valiv akadeemiline kirjutus on puhas kulutus Bataille' mõttes, omamoodi püha rituaal. Pole ime, et igasugused Oki raportid ja muud popsiliku, piiratud ökonoomilise mõtlemise derivaadid üritavad säärast tegevust lõpetada.

Bataille' energeetiliste eeldustega saab mõistagi vaielda, ennekõike saab kritiseerida just inimlikuks kasutuseks kõlbliku, piisavalt tihedalt kontsentreeritud energia külluse eeldust (Stoekl 2007). Kuid ka Bataille' eelduste omaksvõtmine ei ole meid viinud ökonoomiast väljapoole, vaid on üksnes avardanud ökonoomilist tasandit. Mitmed kaasaegsed mõtlejad (nt Jacques Derrida, Jean-Luc Marion) on seevastu arutlenud sellise anni võimalikkuse üle, mis ei oleks enam ringlusse asetuv kink. Eelneva arutluse pinnal tundub meid kummitavat omamoodi Midase-probeem: iga asi, iga objekt neeldub paratamatult ökonoomilisse ringlusse; see juhtub isegi puhta kulutuse korral. Derrida sõnastab selle probleemi nii:

And võib olla kui tahes helde, aga kui teda riivab arvestus ja ta hakkab lootma tunnetuse [connaissance] või tunnustuse [reconnaissance] peale, siis laseb ta end kohe tehingutesse kaasata: ta vahetab, annab kokkuvõttes valeraha, sest annab palga vastu (Derrida 2011: 155-156).

Nii Bataille kui ka Derrida jõuavad järeldusele, et püha saab juhtuda vaid teispool asju (Bataille 1997: 206, 210), and ei saa olla asi: 
...tuleb liikuda edasi objekti teise tühistamise juurde: annist tuleb alles jätta ainult andmine, andmise akt ja intentsioon, mitte antu, mis lõpuks midagi ei loe. Anda tuleks ilma sellest teadmata, ilma tunnetuse ja tunnustuseta, ilma tänuta: ilma milletagi, igal juhul ilma objektita (Derrida 2011: 156).

Jean-Luc Marion üritab vestluses Derridaga tõlgendada anni asjatust hoomataval moel, kaaludes võimaliku annina juhtumeid, kus andja jääb anonüümseks (nt kui Robinson Crusoe leidis midagi kaldalt ega olnud kindel, kas ese on sattunud sinna juhuslikult või kellegi poolt talle ette sokutatud); kus me anname kellelegi oma aega, elu või surma, anname oma sõna; Marioni jaoks on keskseks kriteeriumiks see, et annil ei tohi olla põhjust (Derrida, Marion 1999: 63). Derrida on oma anni-käsituses radikaalsem ja paradoksaalsem:

...on võimatu, et and ilmuks kui selline. [---] Ma ütlesin, et kui leidub andi, peab see niisuguse võimatuse tõttu olema sellesama võimatuse kogemus, ja see peab ilmuma kui võimatu. Anniks nimetatud sündmus on teoreetilise identifikatsiooni jaoks totaalselt heterogeenne (Derrida, Marion 1999: 59).

Derrida jaoks saab olemas olla üksnes anni võimatuse kogemus, mille kohta ei saa midagi teada, kuid mida saab mõelda (Derrida, Marion 1999: 60). Lisaks antava objekti puudumisele ei tohi anni puhul seega olla ka andmise, vastuvõtmise ega tänamise kogemust:

Niipea kui saaja teab, et see on and, tänab ta andjat ja tühistab anni. Niipea kui andja on teadlik andmisest, tänab ta iseennast ja jällegi tühistab anni, taashõlmates selle ökonoomilisse ringi (Derrida, Marion 1999: 59).

Lisaks asjade ökonoomilisele ringlusele peab anni puhul katkema seega ka märkide ja tähenduste ökonoomia (vrd Baudrillard 1988a).

Kas Derrida väljamurre ökonoomiast õnnestub? Kuigi ta omistab endale sellise taotluse (Derrida, Marion 1999: 59), on seda tema mõeldu põhjal raske hinnata. Näiteks Aabrahami ohverduse analüüsis järeldab Derrida, et (viimsel hetkel peatatud) koletus ohverduses avaldub siiski üks teine, mõõduta ökonoomia (Derrida 2011: 147): ohverduse saladuse kummaline ökonoomia (Derrida 2011: 140), mis opereerib Jumala poolt antava lõputu tasuga (Derrida 2011: 150). ${ }^{13}$

Mis oleksid selle mõttekäigu järeldused raamatu suhtes? Isegi kui and on olemas, ei saa raamat olla and kui selline, kuid ehk saab ta vahendada Derrida mainitud unistust puhtast annist (Derrida, Marion 1999: 72), kanda võimatuse poole liikumise paatost? On ju eelnevalt refereeritud mõtlejate arutlused annist meile vahendatud samuti põhiliselt raamatute kaudu. Sellise funktsiooni täitmiseks peaks raamatu lugemise kogemus hõlmama endas vähemalt kaht reduktsiooni.

Esiteks peab anni poole liikumiseks raamat kui objekt lugemise käigus n-ö kaduma, haihtuma - enamasti see ju eduka lugemiskogemuse käigus juhtubki. Me ei jõllita raamatut, ei mõtle temast, vaid neeldume sisusse. Kuid

\footnotetext{
${ }^{13}$ Pascali kihlveo-argumendis tõestatakse otsesõnu Jumalale kui lõputule hüvele panustamise kasulikkus (Pascal 1998: 133-137).
} 
samuti võib ette kujutada mitmeid olukordi, kus selline haihtumine ei õnnestu, raamat tuletab ennast oma materiaalsuses häirivalt meelde: näiteks oma kehva trükitehnika või köite tõttu või siis, vastupidi, paelub meid luksusliku nahkköite lõhn; kindlasti võib lugejat häirida ka mõni raamatu soetamisega seotud aspekt - näiteks kõrge hind, mis paneb üha küsima, kas lugemiskogemus ennast ikka ära tasub, vms.

Teiseks peab raamatu kaante vahel puhta anni paatost kandev teos olema ebalev, ta ei tohi lugejale mõjuda särava eneseküllase teooriana või narratiivina. Iga teos, mis on vähegi loetav, mis keelelise tähistamise seoseid lõplikult ei katkesta, taastoodab paratamatult seda, mida Baudrillard nimetas märgi poliitökonoomiaks. Küsimus on selles, kuidas liikuda tähistamise piiride poole, vaikuse poole, puhta anni poole; kuidas olla mittemidagiütlev ja kasutu. See küsimus seab kimbatusse nii mõtlemise kui ka kirjanduse, just selles kimbatuses on need kaks minu nihilismi mõtlemise kohaselt omavahel kokku sulamas.

Alateema lõpetuseks olgu mainitud, et puhta anni võimatuse kogemus ei pea mitte tingimata olema eetiline kogemus levinaslikus tähenduses, nagu see on kahtlemata hilise Heideggeri puhul, kes kõneleb mõtlemisest kui ootamisest, maldamisest (sks Gelassenheit: Heidegger 1983), tänulikkusest objektitu ei-lise anni (Gabe) eest (Heidegger 1988). Kuigi nii Bataille kui ka Derrida analüüsivad muuhulgas (vägivaldse) surma andmist (Bataille 1997: 213; Derrida 2011), kipub ka hilise Derrida mõtlemine kalduma üheselt eetilise respekti suunas. Säärase käsituse ühekülgsust kritiseerisin oma monograafias (Luks 2015, ptk 5) ning kohtasin sama etteheidet ka hiljuti ilmunud Laclau-kogumikus (Laclau 2015: 236-239).

Tuleb öelda, et siiani mõeldu põhjal tuvastasin annist unistamise, mis leiab aset mõtlemises ja kunstis; raamat võib olla selles unistamises osaline, kuid selleks peab ta esemena lugemisaktis haihtuma. On raske tõrjuda kõhklusi, et annile lähemal on need mõtted, mida ei avaldata raamatus ega kusagil mujal, mis jäävadki salajasse või pelgalt võimalikkusse (vt ka Tomberg 2011: 157-174).

\section{Raamat kui fetiš}

Eelmise peatüki mõttekäikudes rõhutasin raamatu esemelisuse loomulikku reduktsiooni lugemiskogemuses. Tähenduste ökonoomia seisukohalt on tähtis üksnes teos, raamat on küll levinud, kuid siiski sattumuslik vorm teose ringlemiseks. Paljude digiajastu jüngrite väitel on tegemist kui mitte välja sureva, siis vähemalt vananenud meediumiga. Siinse mõtiskluse viimase käiguna võtame kaalumisele vastupidise lähenemise, vaatleme raamatuid kui asju lahus nende sisust. See aspekt tundub olevat raamatute tekkepõhjuste seas kõrvaline, kuid ei pruugi seda ometi olla. ${ }^{14}$ Järgnevalt ei tõsta ma raamatu asisust esile mitte otsitud filosoofilise pingutuse korras, vaid võtan vaatluse alla raamatu seda külge hindavad kirglikud hoiakud elust enesest. Minu hinnangul on õigustatud nimetada säärast kirglikku suhet fetišismiks.

Fetiši mõiste on tänapäeval üldkäibiv ennekõike seksuaalses kontekstis, ometi on seda mitmel moel kasutatud sõna tänini vähe analüüsitud

${ }^{14}$ Esmase tõuke siinseks mõttekäiguks andis Ülo Matjuse ettekanne „Raamat kui asi” (2001). 
(Baudrillard 1981: 88). Termini esmane tähendus pärineb religiooniantropoloogiast (termini juurutajaks oli Charles de Brosses), fetišismiks nimetati maiste, materiaalsete objektide kummardamist n-ö primitiivsetes kultuurides (Pietz 1996: 131), mida peeti transtsendentset ainujumalat kummardava kristluse lähtekohalt algeliseks ja tobedaks. Kõikides hilisemates kontekstides ongi fetiši mõistele jäänud külge negatiivne hinnang, nt „Eesti keele seletav sõnaraamat" defineerib seda nõnda:

fetiš $\langle-\mathrm{i} 2\rangle\langle\mathrm{S}\rangle$.

1. ETN kultuslikult kummardatav ese, millele omistatakse üleloomulikku maagilist jõudu (peamiselt loodusrahvail).

2. PILTL liialdatud austamise objekt. Fetišiks tõstetud teos. ${ }^{15}$

Antud määratlustes ei sisaldu üks eelnevatega seotud tähendusaspekt, mis on kesksel kohal Marxi kaubafetišismi käsituses. Nimelt tahab Marx näidata, et mis tahes asja rahalise hinna (ehk vahetusväärtuse) käsitamine omaette asjana, uurimist vääriva tegelikkusena on mõtlemisviga, kuna tegelikult on kauba hind „ainult kindel ühiskondlik suhe inimeste eneste vahel, mis siin omandab nende silmis asjadevahelise suhte fantastilise vormi" (Marx 1953: 71). Asjade käsitamine kaupadena on tervikuna Marxi jaoks fetišism (Marx 1953: 71) - selles hinnangus ei sisaldu mitte üksnes süüdistus kauba liialdatud austamises, vaid ka milleski sellises, mida Gilbert Ryle (1996) nimetas hiljem keha ja vaimu suhet analüüsides kategooriaveaks: inimlikud tootlikud suhted on asetatud valesse kategooriasse (objekti, täpsemalt kaupa). Ka etümoloogiliselt tuleneb fetiši mõiste väidetavalt fabritseerimisest (vrd ingl fake) ja petmisest (vt Baudrillard 1981: 91).

Kui jätta vähemalt esialgu kehtima eeldus, et raamatuid trükitakse lugemiseks, sisu pärast (loomulik funktsioon), siis on täiesti õigustatud nimetada kõiki teisi raamatu n-ö kummardamise viise liialdatuks (ebaloomulikuks). Kõige tuntum sellise fetišismi vorm on bibliofillia, raamatute kogumise kirg. Sellest kirest pole küllap vaba ükski raamatusõber. Tundub, et raamatutes peitub mingi fetiši mõiste esmatähendusele omane üleloomulik maagiline jõud, mille seletamisega võiksid hakkama saada sotsioloogid ja antropoloogid. Esmane pähe tükkiv hüpotees viib mõtted mõistagi piiblile kui salajasele fetišile puuslike vormimist keelavas monoteismis. ${ }^{16} \mathrm{Ma}$ ei arva, et ma liialdan, väites, et soov enda kirjutatud raamatut füüsilisel kujul näha ja käes hoida on üks olulisim inimesi raamatute avaldamise poole tõukav impulss. Küllap motiveeris just see asjaolu mindki olulisel määral avaldamisele eelnevat vintsutuste kadalippu läbima - oli ju monograafia sisu valdavas osas varem artiklites ja doktoritöös avalikustatud.

Nõustugem arutluse huvides hüpoteesiga, et raamatu kui fetiši ihaldamine on oluline jõud, mis tõukab inimesi raamatute avaldamise suunas. ${ }^{17}$ Sel juhul jääb veel üle küsida: kas see olukord on taunitav, paheline? Mõistagi võib leida levinud argumente liigse avaldamise vastu: liiga palju raamatuid, infomüra, avaldamise tähtsuse devalveerumine, metsade hävitamine jne (vt Zaid

\footnotetext{
${ }^{15} \mathrm{http} / / / \mathrm{www} . e k i . e e /$ dict/ekss/index.cgi?Q=feti\%C5\%A1\&F=M

16 Testjuhtumina võiks uurida, kas moodsa aja kristlased on varmad ka pühakirja e-lugeritest lugema.

${ }^{17}$ Ka see iha võib maskeeruda mitmesse enesepettuse vormi, ennekõike kinnitusse, et raamatu sisu on tähtis, publik vajab raamatut.
} 
2011). Samas võib eelnevalt eeldatud raamatu loomulikust funktsioonist lähtudes konstrueerida ka argumente raamatufetišismi kaitseks: tugevaim neist tundub olevat tõdemus, et iha raamatute järele on pea alati seotud keskmisest suurema lugemisharjumusega; ${ }^{18}$ raamatute hulk kodus on sotsioloogide väitel positiivses seoses laste haridusliku edenemisega jne.

Liikugem lõpetuseks raamatu näite juurest üldisele tasandile ja küsigem: kas fetišismis on ülepea midagi taunitavat? Tasub tõsiselt võtta Baudrillard'i hoiatust vaadeldava mõiste riukalikkuse kohta; fetišism ei toimi kuigi tõhusalt kriitilise metakeele terminina (nt Marxi poolt demüstifitseeritud kaubafetišismi saladus pole vaatamata pidevale kordamisele vähendanud karvavõrdki üldist kaupade ringlust ja turuhinna abil tehtavaid rehkendusi), küll aga pöördub mõiste selle kasutajate vastu ja tekitab uusi maagilise mõtlemise vorme (Baudrillard 1981: 90; vt ka Nancy 2004: 143). Iga käsitus, mis nimetab mis tahes objekti negatiivselt hinnates fetišiks ning säärast vaadet järelikult väärteadvuse vormiks, on fundatsionalistlik, eeldab mittevõõrandunud vaate võimalikkust, asjade loomulikku korda ja inimkogukonna loomulikku moraalset korda. See tähelepanek ei tee ettevaatlikuks mitte üksnes minu poolt vaatlusaluses teoses arendatud nihilismi mõtlemist, vaid paljusid postfundatsionalistlikke filosoofe.

Lähtudes nihilismi mõtlemise metafüüsilisest lähtekohast: ei ole „objektiivset reaalsust”, vaid üksnes faablite põiminguna üles ehituvad maailmad (Luks 2015: 84-90), pole olemas ka ühtegi pseudoobjekti per se. Lähtudes nihilismi mõtlemise amoraalsest lähtekohast - kõik on lubatud -, ei saa tembeldada kui tahes intensiivset huvi kui tahes imeliku ontoloogilise staatusega objekti suhtes ülemääraseks. Säärased otsustused saavad olla üksnes kitsalt kontekstuaalsed. Näiteks võib inimese kirge posijate ja pseudoteaduslike ravimite (nt MMS) suhtes pidada kahjulikuks üksnes eeldades, et a) inimese võimalikult hea tervis on säärasest huvist tähtsam ja b) teaduslik meditsiin suudab inimesi posijatest paremini ravida. See arutlus on puhtalt ökonoomiline, kuid kui tegemist on tavameditsiini prognooside kohaselt surmahaige inimesega, seega piirsituatsioonis viibiva inimesega, siis vaevalt on tööriista rehkendamaks, millise väärtusega tema jaoks võib olla posijate lubatud imesse lootmine. Inimese kontsentreeritud iha mõne fetiši vastu (nt tavatu seksuaalobjekt, narkootikum) on ülemäärane üksnes juhul, kui fetiši kummardamine paralüseerib ülejäänud elu toimivuse (nt sõltuvushäire), ja sedagi eeldusel, et see inimene soovib igakülgset elu jätkata, pole otsustanud fetiši teenimisega n-ö lõpuni minna. ${ }^{19}$ Sageli tulenevad fetiši kummardamisega kaasnevad komplikatsioonid otseselt kogukonnast, ebahariliku eluviisi vaenamisest.

Kui äärmuslikud juhtumid kõrvale jätta, julgeksin üldistada, et fetiši maagiline vägi aitab inimese elu mõttekaks muuta. Küsigem korraks: mis võiks olla tunnetuslikus plaanis fetišismi vastand? Selleks on argine asjade kasutusseostesse neeldumise automatism, mida Heidegger nimetas „Olemises ja ajas” käepärasuseks (sks Zuhandenheit) (Heidegger 1967: 69 jj); Lev Tolstoi hinnangul on selline tunnetuslik seisund sama hea kui üldse mitte elada:

${ }^{18}$ Nõnda oli see ka äärmusliku raamatufetišisti professor Kieni puhul Elias Canetti romaanis „Pimestus”.

${ }^{19}$ Jätan siinkohal kõrvale kahtlemata olulised küsimused tahtenõrkusest ning teovõimetusest, mis on praktilises plaanis isiku seisundi hindamisel väga olulised. 
Pühkisin toas tolmu ja jõudes ringiga diivani juurde, ei suutnud ma meenutada, kas olin seda juba pühkinud või ei. Et need liigutused on harjumuspärased ja ebateadlikud, ei suutnud ma meenutada ning tundsin, et seda on juba võimatugi meenutada. Nii et kui ma oleksin pühkinud ka tolmu ära ja selle unustanud, s.t kui ma oleksin tegutsenud ebateadlikult, siis oleks see olnud sama hea, nagu seda poleks olnudki. Kui keegi teadlik inimene oleks näinud, siis võiks selle taastada. Aga kui keegi ei näinud või nägi, kuid ebateadlikult, kui paljude inimeste terve keeruline elu möödub ebateadlikult, siis seda elu poleks nagu olnudki (Lev Tolstoi päevikust, tsit Šklovski 2014: 22-23).

Fetiš seevastu pole lihtsalt tähele pandud asi, vaid ihalemisobjekt, mida vaadeldakse intensiivse pilguga (Nancy 2004: 144), mis puudutab inimest sügavalt - ükskõik kas tegemist on meeleliselt tajutava objektiga, nagu raamat, või pelgalt mõeldava asjaga (Jumal, Eesti asi). ${ }^{20}$ Jean-Luc Nancy hüpoteesi kohaselt võib fetiš olla presentsuse kui sellise saladus; jõud, mis suunab mind seostuma asjade presentsusega (2004: 144). Isegi kui oletada, et selles seostumises toimib mingisugune ihale omane ökonoomiline protsess, on fetišismi erinevad vormid ometigi väljamurdeks kõledast homo oeconomicus'e positsioonist, siin pannakse erinevad identiteediloome faablid liikuma, fetišit teenides ei rehkendata selleks kuluvaid ressursse ja aega, inimesest saab homo ludens (vt Huizinga 2004).

Eelnevast võib jääda mulje, et igasugune suhestumine fetišiga on suure inimese mäng, vaba aja veetmise tegevus. Ometi võimaldavad eelnevalt toodud näited jõuda palju laiemate üldistusteni: fetišid eespool avatud tähenduses on nii mis tahes isikliku maailmavaate kui ka kultuuri südamikuks (Baudrillard 1988a: 92; Pietz 1996: 125). Tavaliselt nimetatakse neid tuumseid fetišeid püsiväärtusteks vms. Marxi tutvustatud kaubafetišism ei ole mitte mõne majandusteadlase veidrus, vaid käibib tänini globaalse kapitalismi keskse mõttemudelina; Eesti tasakaalus eelarve fetišism kujundab meie ühiskonna üldist ilmet ja inimsaatusi; parateaduste kummardamine ei saa jääda süütuks kõrvalhobiks, vaid muutub pigem inimese identiteedi põhiliseks tunnuseks jne. Viimases näites ilmnev n-ö alternatiivse elutõe otsimine ei näita antud nurga alt vaadates mitte seda, et fetišismile omasest „väärteadvusest” on võimalik vabaneda; pigem on asi selles, et peavoolukultuuri poolt pakutav nüri vaatemäng ei suuda luua objekte, mis mõjuksid ärksama tundeeluga inimestele fetišitena. Just seda pidas silmas Guy Debord, kõneldes vaatemänguühiskonna ajastust ilma ühegi pidupäevata (Debord 2013: 122), või Jean Baudrillard (1988b), kõneldes üldisest kommunikatsiooni ekstaasist, kus pole ühtegi võrgutust. Tundub, et kui ma kirjutasin naljaga pooleks laastu „Valimislubadus”: „Igale perverdile oma fetiš!” (Luks 2013: 25), siis peitus selles killus sügavam emantsipatsiooniidee, kui ma ise hoomasin.

${ }^{20}$ Ernesto Laclau paljulubava analüüsi kohaselt on ideoloogiate, aga ka laiemalt maailmavaadete südamikuks just säärased abstraktsed ebamäärased-sisutühjad asjad (Slavoj Žižeki (2003) järgi ülevad objektid), mis opereerivad keeles tühjade ja hõljuvate tähistajatena, organiseerides oma tühjuse ümber teisi konkreetseid tähendusi. Ka Baudrillard (1981: 92-93) rõhutab, et fetiši puhul ihaldatakse ja nauditakse süsteemi, koodi; kõige taga on tähistaja fetišism. Lyotard (1991: 105) paneb tähele, et ka kapitalismis on midagi ülevat, nimelt lõputu rikkuse esitamatu idee. Selles mõttesuunas on suur potentsiaal fetiši seostamiseks negatiivsusega, ometi jääb see praeguse arutluse teemast väljapoole. 


\section{Kirjandus}

Allik, Jüri 2014. Publitseerimise huvitav maailm. - Akadeemia, nr 9, lk 15501576.

B a r the s, Roland 2007. Tekstimõnu. Tlk Tanel Lepsoo. Tallinn: Varrak.

Bataille, Georges 1997. The Bataille Reader. Toim Fred Botting, Scott Wilson. Oxford: Blackwell Publishing.

B a u drillard, Jean 1981. Fetishism and ideology: The semiological reduction. J. Baudrillard, For a Critique of the Political Economy of the Sign. Tlk Charles Levin. St. Louis: Telos Press, lk 88-101.

Baudrillard, Jean 1988a. For a critique of the political economy of the sign. - J. Baudrillard, Selected Writings. Stanford: Stanford University Press, lk 57-97.

B a u d rillar d, Jean 1988b. The Ecstasy of Communication. Tlk Bernard Schutze, Caroline Schutze. New York-Brooklyn: Semiotext(e).

Bulgakov, Sergei 2000. Philosophy of Economy. The World as Household. New Haven-London: Yale University Press.

D e b o r d, Guy 2013. Vaatemänguühiskond. Tlk Anti Saar. Tallinn: TLÜ Kirjastus. D e r r i d a, Jacques 2011. Surma and. Tlk Mart Kangur. Tallinn: TLÜ Kirjastus.

Derrida, Marion 1999 = On the Gift: A Discussion Between Jacques Derrida and Jean-Luc Marion, moderated by Richard Kearney. - God, the Gift, and Postmodernism. Toim John D. Caputo, Michael J. Scanlon. Bloomington: Indiana University Press.

Foucault, Michel 2005. Teadmiste arheoloogia. Tlk Kaia Sisask. Tartu: Tartu Ülikooli Kirjastus.

Go u x, Jean-Joseph 1990. General Economics and Postmodern Capitalism. - Yale French Studies, nr 78, lk 206-224.

Hei d e g g e r, Martin 1961. Nietzsche 2. Pfullingen: Neske.

He i d e g g e r, Martin 1967. Sein und Zeit. Tübingen: Niemeyer.

Heidegger, Martin 1983. Zur Erörterung der Gelassenheit. Aus einem Feldweg-gespräch über das Denken. - M. Heidegger, Gesamtausgabe, I Abteilung, Bd 13, Aus der Ehrfahrung des Denkens. Frankfurt am Main: Vittorio Klostermann, lk 37-74.

Hei d e g g er, Martin 1988. Zur Sache des Denkens. Tübingen: Niemeyer.

H u i z ing a, Johan 2004. Mängiv inimene. Kultuuri mänguelemendi määratlemise katse. Tlk Mati Sirkel. Tallinn: Varrak.

Käärik, Henn 2013. Klassikaline ja nüüdisaegne sotsioloogiline teooria. Õpik kõrgkoolidele. Tartu: Tartu Ülikooli Kirjastus.

Lacla u, Ernesto 2015. Antagonism, poliitika, hegemoonia. Valik esseid. Koost ja toim Jüri Lipping, tlk Andro Kitus, Hasso Krull, J. Lipping, Martin Mölder, Peeter Selg, Tanel Vallimäe. Tartu: EYS Veljesto.

L u k s, Leo 2013. 100\% leo luks. Saarde-Pärnu: Ji.

Luks, Leo 2015. Nihilism ja kirjandus. Ei kogemine filosoofia ja kirjanduse ühtesulamisel. (Acta Universitatis Tallinnensis. Humaniora.) Tallinn: TLÜ Kirjastus.

Ly ot a r d, Jean-François 1991. The Inhuman. Reflections on Time. Tlk Geoffrey Bennington, Rachel Bowlby. Cambridge: Polity Press.

M a rx, Karl 1953. Kapital. Poliitilise ökonoomia kriitika. Esimene köide. Tallinn: Eesti Riiklik Kirjastus. 
Matju s, Ülo 2001. Raamat kui asi. - Kloostrist Internetini. Toim Tõnu Tender. Tartu: Eesti Raamatu Aasta Peakomitee, lk 91-100.

M a u s s, Marcel 2015. Essee kingist. Tlk Anti Saar. Tallinn: TLÜ Kirjastus.

Mereste, Uno 1980. Terminid ökonoomia, ökonoomika ja majandus. - Keel ja Kirjandus, nr 3, lk 173-176.

$\mathrm{N}$ a n c y, Jean-Luc 2004. The two secrets of the fetish. - Journal of Visual Art Practice, kd 3, nr 2, lk 139-147.

P a s c a l, Blaise 1998. Mõtted. Tlk Kristiina Ross. Tallinn: Hortus Litterarum.

Pietz, William 1996. Fetishism and materialism: The limits of theory in Marx. Fetishism as Cultural Discourse. Toim Emily Apter, W. Pietz. Ithaka-London: Cornell University Press, lk 119-151.

Ryle, Gilbert 1996. Descartes'i müüt. Tlk Anto Unt. - Akadeemia, nr 8, lk 16661680.

S t o ek l, Allan 2007. Excess and depletion: Bataille's surprisingly ethical model of expenditure. - Reading Bataille Now. Toim Shannon Winnubst. BloomingtonIndianapolis: Indiana University Press, lk 252-282.

Šklovs ki, Viktor 2014. Kunst kui võte. Tlk Boris Kabur. - Kirjandus kui selline. Valik vene vormikoolkonna tekste. Koost ja toim Märt Väljataga. Tallinn: TLÜ Kirjastus, lk 17-35.

Z a i d, Gabriel 2011. Liiga palju raamatuid. Tlk Kätlin Kaldmaa. Tallinn: SA Kultuurileht.

Ži ž e k, Slavoj 2003. Ideoloogia ülev objekt. Tlk Hasso Krull. Tallinn: Vagabund.

T o m b e r g, Jaak 2011. Kirjanduse lepitav otstarve. Tallinn-Tartu: Tartu Ülikooli Kirjastus.

To ol, Andrus 2014. Objektiivsuse teema Wilhelm Dilthey vaimuteaduste-filosoofias. Tartu: Tartu Ülikooli Kirjastus.

\section{Why publish a monograph?}

Keywords: philosophy, publishing, economic value, symbolic capital, gift, fetish

The research question is whether conscious choices are totally or at least predominantly economic, based on a calculation of gains and losses. The article does not seek a final solution, though, narrowing down to the conceivable principles of publishing a humanities monograph in Estonian. Case analysis is applied to the author's recent experience in monograph publishing.

Part One explores the possibility of interpreting a book (monograph) to be published as an economic item. The analysis is not confined within the classical system of market economy as the prospective book is also discussed as symbolic capital and even as a source of possible pleasures enjoyed in the process of publication. Based on Jean Baudrillard it is shown that an emphasis on the value in use will not relieve us from the calculating thinking mentioned above. It is concluded that the publication of a humanities monograph in Estonian does not seem to be profitable in any above aspect.

Part Two analyses the possibility of approaching the prospective book as a pure gift, outside of any economic calculation. Although modern continental philosophy is rather fond of seeking a gift, it is not so simple to classify the publication of a book as a pure gift. The main counter-argument is that of the gift economy 
launched by Marcel Mauss, further developed into a system of general economy by George Bataille, with profitless expenditure as a central concept. And yet it is not forbidden to seek an impossible gift, which on certain conditions may as well be the publication of a book.

Part Three concentrates on the prospective book as a desirable physical object. Such desire justifies the book being called a fetish. A fetishistic desire explains, at least partly, the passion of collecting books, but it also motivates people to write them. The final conclusion reads that as fetishes help add meaning to life there is nothing wrong in worshipping them.

Leo Luks (b. 1976), PhD, Estonian University of Life Sciences, Assistant Professor of Philosophy; Teacher of Philosophy at Herbert Masing School, Tartu,leoluks@hot.ee 